\title{
Examining the Relationship between Economic Variables and Financial Performance of the Companies in Tehran Stock Exchange
}

\author{
Ali Akbar Nazari ${ }^{1}$, Mohammad Taher Ahmadi Shadmehri ${ }^{2}$ \\ ${ }^{1}$ Ferdowsi University of Mashhad, International Campus Mashhad, Iran \\ ${ }^{2}$ Department of Economics, Ferdowsi University of Mashhad, Iran \\ Correspondence: Mohammad Taher Ahmadi Shadmehri, Associate Professor Department of Economics, Ferdowsi \\ University of Mashhad, Iran. E-mail: shadmhri@um.ac.ir
}

\author{
Received: May 4, 2015 \\ doi:10.5539/ibr.v9n7p188 \\ Accepted: May 13, $2015 \quad$ Online Published: June 21, 2016 \\ URL: http://dx.doi.org/10.5539/ibr.v9n7p188
}

\begin{abstract}
This study aims to identify long-term financial performance of the companies in Tehran Stock Exchange and some economic variables like inflation rate, liquidity growth rate, exchange rate, and oil income. In this study, data was analyzed in a quarterly form from 2005-2013 using self-regression with distributional lags. Results of co-integration test showed a long-term correlation between economic variables and growth rate of cash return index. The long-term correlation between growth rate of cash return index and oil return and exchange rate was negative while the correlation between growth rate of cash return index and inflation rate was positive. Also, the significance of cash growth rate coefficient was rejected at $90 \%$ significance level.
\end{abstract}

Keywords: economic variables, cash return index of the stock, self-regression with distributional lags, monetary theory of inflation, arbitrage pricing theory

\section{Introduction}

In studying the behavior of effective factors in the market and market economics, searching for the variables that can explain the correlation of financial section of the economics with the real section of economics is of great importance. Money and capital markets as the components of financial sections handle the duty of resource provision for the real section of economy. Efficiency of financial sections causes optimum allocation of scarce activities to economic activities. Optimum allocation of resources leads to the optimization of savings and investments, and national economy growth. Economists like Goldsmith (1969), Miknon (1973) and Shaw (1973) believed that financial markets play a key role in the economic development. In their beliefs, difference in the quality and quantity of offered services by financial institutes can identify an important part of the difference in the growth rate of the countries.

In the pursue of post war economic policies of the government and for attracting public cooperation in investment and directing static investments towards dynamic economic activities and providing financial needs of manufacturing corporations and producing required goods, Tehran Stock Exchange restarted its activities in a broader form from 1991. From then on, economic conditions after war and the effects of the changes from economic variables like inflation rate and stock market index have witnessed volatility. First reason for the research on the effects of economic variables on stock return is that it can affect the ways of stock pricing. It can meet a main section of investors and stockholders' needs. Undoubtedly, meeting this need via correct direction of economic revolutions blooms capital market in a way that cash demand and supply in the market becomes more efficient than before. Developing financial investment (v.s investment on real assets) is a feature of developed economies. Developing capital market and advanced financial institutes facilitate real investments. In fact, financial and real investments complement each other. The importance of pricing financial assets leads to the creation of various theories and models in the recent century. Models of Markowits (1952), Sharp (1963), Linter (1965), Mousin (1966), Ross (1976), and Shouls (1973) are the most famous ones. Designing advanced models and using IT technology lead to different estimations from the risk and return of financial assets. Another reason for doing the present study is assisting correct pricing of financial assets and usefulness of new studies in relation with examining the effects of economic information on stock price. Studies in America guaranty main changes in understanding the ways of pricing financial assets. Fama and French (1993) showed that limiting systematic risk to one factor based on the pricing model of capital assets can't help understanding investors and stockholders. Thus, attention to the effects of other factors like economic variables can be important. This study aims to find an approach for using economic information in this field. Regarding the main role of the government in running economy and 
decision-makings and the effects of public policies on stock market, studies on the effect of economic factors like inflation rate, interest, foreign exchange rate, cash growth rate, and etc on stock return can give a new understanding in this regard. In this way, investors and stockholders can predict the effects of these economic decisions on index changes and stock price.

This study identifies long-term financial performance of the companies in Tehran Stock Exchange and some economic variables like inflation rate, liquidity growth rate, exchange rate, and oil income. In this study, data was analyzed in a quarterly form from 2005-2013 using self-regression with distributional lags. This study uses a proper pattern of monthly time series of inflation, cash growth rate, exchange rate, oil income, and cash return. To test the relationship of these variables, ARDL pattern is used.

The rest of this paper is as follows: section 2 explains theoretical background of the study. Section 3 is the background of the study. Section 4 is allocated to methodology and hypotheses. Section 5 explains the results. Section 6 concludes the findings. Section 7 offers suggestions from the study. Then, the references are represented.

\section{Theoretical Background}

Stock prices can be identified by some economic variables like interest rate, foreign exchange rate, and inflation rate. Different studies have shown the effect of economic forces on stock return of different countries. For example, the theory of arbitrage pricing by Ross (1976) and Chen et al. (1986) was introduced for expressing the effect of some economic variables on stock return in the capital market of America. Their findings showed that industrial productions, changes in risk and changes in term risk have a positive correlation with the return of expected stocks. This is while the correlation of predicted inflation rate and unpredicted inflation rate with expected stock return is significantly negative.

Ross (1976) suggested the theory of arbitrage pricing as a replacement for capital asset pricing. This model starts with the point that how investors can create an efficient investment portfolio. But, arbitrage pricing theory looks from a different perspective at the risk or its measurement and doesn't look for efficient investment portfolios. Its basis is that stock prices are modified when stockholders' search for arbitrage returns. When arbitrage returns are removed, it is said that stock prices are balanced. Definition of market efficiency in this theory refers to the lack of arbitrage situation. Advocates of this theory suggest that this model has two advantages compared with capital assets pricing model. First, arbitrage pricing theory suggests suppositions about investors' preferences about risk and return, claiming that it has lower limitations. Second, they believed that this model can be experimentally reliable. The main point in arbitrage pricing theory is identifying effective factors and discrimination of predicted changes from unpredicted variations in measuring sensitivities (Fisher and Jordan, 1991).

Arbitrage pricing theory identifies the real return of securities as a function of economic variables. Despite capital asset pricing model, this model provides the possibility of using more than one factor of systematic risk. In a stock portfolio, specific risk of a share is not important. Error terms of individual stocks are not interdependent and their correlation coefficient is zero. In these conditions, only variables' risk is important, showing that systematic risk can't be removed. But, unsystematic risk can be omitted with variation in investment. Roll and Ross (1980; 1984) and Chen et al. (1986) believed that the fact lies in five economic factors and different stocks have different sensitivities towards these five systematic risks. These factors form a main section of the origin of stock portfolio. These five factors include changes in predicted inflation rate, unpredicted changes in inflation rate, unpredicted changes in industrial productions, unpredicted changes in the return till differential usance of cheap and premium securities, and unpredicted changes in the return till differential usance of long-term and short-term securities.

Three first factors affect cash flows of economic corporations, stock return and its growth. Two latter factors affect interest rate and stock evaluation. Based on this model, investors set stock portfolio based on their tendency to face the risk of each five factors. Because, different investors have different tastes in relation to risk. Different tests on the pattern of arbitrage pricing pattern showed that this theory exceeds capital pricing model (Chen, 1983). With such a perception from arbitrage pricing pattern, the relationship between stock price and the factors of such model can be estimated to have a predictability power for the future by modeling economic factors and supposing reasonable action of stock market. Following Chen et al. (1986), Poon and Taylor (1991) conducted a study in English market. They showed that economic micro-variables don't affect stock return in England. This conclusion was against the findings in stock market of America. This difference may come from the fact that either other microeconomic variables affected stock return in England or the used methodology by Chen et al. (1986) has been inefficient. As one of the most important economic variables affecting stock price, inflation has been considered important. The relationship of inflation and stock return is a challenging issue among the scholars. Balance in the market doesn't appear based on nominal values and investors consider inflation as an important micro-economic variables in decision-making for an investment. If inflation can be predictable, investors increase some value added percentage as inflation to their expected return and the market reaches equilibrium. Thus, till inflation is predictable, uncertainty disappears and share risk with 
systematic or unsystematic risk can be identified regardless of the fact that these risks have been estimated based on real values or nominal values. But, the conditions differ when the inflation is unexpected and unpredictable. In inflation conditions, nominal return of the companies increases after a while. In fact, profitability doesn't increase but the nominal profit enhances for the inflation. When nominal profit enhances, nominal stock price increases. Another inflation effect is decreasing natural value of each share. When inflation rate is high, the quality of real profit of the companies decreases. Moreover, inflation conditions decrease purchase power of the people. Increase of life costs is in a way that investment and saving chance is taken from them and incomes are spent for current costs. From the other hand, investment decrease reduces demands for investment in stock market and stock index. Also, Ross and Roll (1980) found a negative correlation between weighted mean return of New York Stock Exchange index and expected and unexpected inflation.

Based on Fisher (1930), expected return's nominal rate should reflect all inflation expectations to yield real rate. Real rate is identified by the factors like capital productivity and time preference of the consumer which is independent from expected inflation.

One of the most important theories about inflation is monetary theory. Based on this theory, inflation is related to improper increase of money volume. Advocates of money originality like Laidler and Parkin (1975) believe that necessary condition for continuous inflation is continuous increase of money supply with a rate over multiplying growth rate of real income and income elasticity of money demand. Monetary theory of inflation can be summarized as follows:

1. Inflation in long-term is a monetary phenomenon. Thus, high and continuous growth rate of money demand causes inflation and low growth of money demand decreases inflation rate.

2. The relationship of prices and money supply is proper in long-term. It means that $10 \%$ of increase in money supply raises general level of prices.

3. The casual relation is from money to price. It means that the changes of money supply are the cause of price changes not the reason for it.

4. Nominal balance of money is exogenous and controllable, identified by money officials. In other words, money supply is not a function of economic micro-variables and activities endogenously. Monetary theories are divided into number one and number two monetary theories. Based on the former, inflation is always a monetary phenomenon which is created by faster growth of money supply compared with real productions. Increase of money supply in short term enhances the real production and employment; but, its effects on real variables are removed in long-term and only increases long-term inflation rate. Based on monetary theory number two, only unpredictable changes of money supply has real effects on the economy. Thus, it can't be used as a regular economic policy. Accordingly, predicted changes of money supply affect prices properly.

The assumption that economic variables like inflation, liquidity, foreign exchange rate, and etc affect the changes of stock prices was accepted as a theory. However, in recent decades, attempts have been utilized to examine the effect of economic forces theoretically and measure its effects experimentally. Dynamic relationship of microeconomic variables and stock return has been broadly studied. The basis of these studies is on the theory that stock prices reflect current value of future cash flows of that share (current value model). Thus, future cash flows and expected return rate are needed. Then, economic variables affect future cash flow and expected return rate, impressing stock prices (Elton and Gruber, 1991).

\section{Background}

Developing co-integration analyses provides the possibility of testing the relationship of economic variables and stock markets. Chen et al. (1986) provide a basis for the idea that a long-term equilibrium exists between stock prices and microeconomic variables. Granger (1986) suggested examining this relationship via co-integration analyses. A collection of time-series variables are co-integrated when they have equal rank with a static linear combination. Such a linear combination shows a long-term relationship among variables (Johansen and Juselius, 1990). Spreading co-integration analyses provides other methods for testing the relationship of microeconomic variables and stock return. Christopher Gan et al. (2006) examined the correlation of stock index of News Land and a set of seven microeconomic variables including inflation rate, foreign exchange rate, GDP, money supply, long-term interest rate, short term interest rate, and domestic retail oil price. Results of Johanson test showed a long-term correlation between stock price index of news land and tested economic variables. Results of Granger test showed that stock price index of News Land is not correlated to Granger's relationship for the changes in economic variables. The reason for that is smallness of News Land stock market compared with stock exchange of other developed countries. Jakoob and Mudsen (2002) probed the casual relationship of Bombay stock price and microeconomic variables like foreign exchange rate, foreign exchange 
savings, and business level. They probed foreign exchange variables, foreign exchange savings, and business level as effective variables in the index of Indian stock price in a quarterly form from April 1990- March 2001. Results showed no casualty of these microeconomic variables and stock price index. Mayasmai and Koh (2000) used monthly data in the frame of time series and multivariate co-integration analysis of Johansen in vector error correction model, examining the long-term relationship of stock market index of Singapore and a collection of microeconomic variables. They found that changes in two variables of real economic activities and industrial productions and business exchanges with changes in stock market index of Singapore are not co-integrated. While, there is a co-integration between changes in Stock Exchange index of Singapore and changes in price level, money supply, short-term and long-term interest rate, and foreign exchange rate. In this co-integration relation, changes in the variables of foreign exchange rate and interest rate are more effective than the changes in money supply and price level. They found that Stock Exchange of Singapore is sensitive to the changes in foreign exchange rate and short-term and long-term interest rate. They used a 3-variable model and examined the indices of Stock Exchange of Singapore, America, and Japan. They found that these indices are highly co-integrated and changes in stock market of America and Japan have main effects on Stock Exchange of Singapore. Especially, Stock Exchange of Singapore has a positive long-term correlation with stock market of America and Japan. Kwon and Shin (1999) used Engle-Granger co-integration and the Granger-causality tests by the model of vector error correction model, finding that Stock Exchange of Korea is co-integrated with economic variables like production index, foreign exchange rate, business equilibrium, and money supply. They found that the index of Stock Exchange of Korea doesn't exceed economic variables. Cheung and $\mathrm{Ng}$ (1998) examined co-integration test of Johanson for the quarterly data of Canada, Germany, Italy, Japan, and America. They found a long term co-movement between national stock index and some economic variables like real oil price, real consumption, real money supply, and real GDP in these five countries. Murindle and Abdollah (1997) found that in Korea, India, and Pakistan, foreign exchange rate cause changes in stock prices. But, in Philippines, stock market price directs foreign exchange transfer rate. Gulnur, Muradoglu Kivilcim, and Metin (1996) examined long term relationship of stock price index of Istanbul with interest rate, foreign exchange rate, inflation rate, and money volume in a quarterly form from 1986-1993 in Turkey. Executing Granger and Johanson method showed that stock price index and monetary variables have long-term correlation. In this way, the correlation of stock price index and money volume is positive while its correlation with foreign exchange rate, interest rate, and inflation rate is negative.

In their study titled "Reactions of stock market to economic news in different economic conditions", Lili and Zvliv (1998) examined the effects of macroeconomic news in different economic conditions on stock exchange of America. They examined the evidences of the effects of unpredicted changes in economic variables like money supply, interest rate, and real economic activities on stock market. They found that unpredicted increase of money supply leads to the immediate increase of interest rate. Increase of interest rate reduces current value of future cash flow and stock prices. Leigh (1997) studied Stock Exchange of Singapore finding that the index of Stock Exchange of Singapore is positively correlated with money supply. Fung and Lie (1990) earned similar results with Leigh in Taiwanese Stock Exchange. Gjerde and Saettem (1999) and Achsani and Strohe (2002) examined local markets like Norwegian and Indonesian markets. They found that stock return is negatively correlated with the changes in interest rate and is positively correlated with oil price changes and real economic activities. Study of Achsani and Strohe (2002) showed that the correlation of stock price and inflation rate is negative. While, this correlation in vague. Moreover, these researchers couldn't identify a strong and effective correlation between stock price, exports, and long-term interest rate. They could find a positive correlation between stock price, GDP, money supply, and foreign exchange rate. Jung Soly (1992) tested casualty of the returns of real activities and inflation using the data of America. He concluded that despite Fisher's theory, nominal stock return and inflation have a negative correlation. But, the correlation of nominal interest rate and inflation is positive. Rahman and Cozier (1988) found a negative correlation of real stock return and inflation in Canada. While, Leonardo Hernandez (1990) found a significant correlation between real stock return and inflation. Unro Lee (1996) concluded a negative and significant correlation between real stock return and inflation. Song, Ramchander and Chatrath (1997) found a negative correlation of real stock return and unexpected inflation parts.

\section{Methodology and Hypotheses}

This study was correlation using descriptive and referential methods for applied goals. Statistical population included all listed companies in Tehran Stock Exchange. Time span of the study was three first months of 2004 till fourth three months of 2012.This study uses a proper pattern of monthly time series of inflation, cash growth rate, exchange rate, oil income, and cash return. To test the relationship of these variables, ARDL pattern was used. It was proved that if a covering vector results from using least squares method based on a self-regressive correlation with distributional s whose $s$ is well defined, the estimator will have minimum normal distribution, lower slope, and higher efficiency. This pattern has some advantages. All variables should not necessarily have equal integration degree. Also, adding coefficient estimation of long-term pattern offers error correction pattern for testing the ways of balancing the lack of 
short term against long-term equilibrium. This approach provides the possibility of testing cointegration when the data of time series are not consistent. General form of an ARDL pattern is as follows:

$$
\mathrm{y}_{\mathrm{t}}=\beta_{0}+\sum_{\mathrm{h}=1}^{\mathrm{p}-1} \eta_{\mathrm{h}} \mathrm{y}_{\mathrm{t}-\mathrm{h}}+\sum_{\mathrm{h}-1}^{\mathrm{p}-1} \lambda_{\mathrm{h}} \mathrm{x}_{\mathrm{t}-\mathrm{h}}+\mathrm{u}_{\mathrm{t}}
$$

Where, $\mathrm{y}_{\mathrm{t}}$ is dependent variable, $\mathrm{x}_{\mathrm{t}}$ is the vector of independent variable, and $\mathrm{ut}$ is an uncorrelated disturbance. Based on Pesaran and Shin (1999), error correction model is as follows:

$$
\Delta \mathrm{y}_{\mathrm{t}}=\alpha_{0}+\sum_{\mathrm{j}=1}^{\mathrm{p}-1} \varphi_{\mathrm{j}}^{*} \Delta \mathrm{y}_{\mathrm{t}-\mathrm{j}}+\sum_{\mathrm{j}=0}^{\mathrm{q}-1} \beta_{\mathrm{j}}^{*} \Delta \mathrm{x}_{\mathrm{t}-\mathrm{j}}+\omega_{0} \mathrm{y}_{\mathrm{t}-1}+\sum_{\mathrm{i}=1}^{\mathrm{k}} \omega_{\mathrm{i}} \mathrm{x}_{\mathrm{i}, \mathrm{t}-\mathrm{1}}+\varepsilon_{\mathrm{t}}
$$

Where, $\mathrm{k}$ is the number of regressors or the number of elements in $\mathrm{x}_{\mathrm{t}}$ vector. In the above pattern, $\mathrm{x}_{\mathrm{i}, \mathrm{t}}$ is exogenous variable. When the coefficients of $\mathrm{x}_{\mathrm{i}, \mathrm{t}-1}$ and $\mathrm{y}_{\mathrm{t}-1}$ are significant , the existance of a cointegration or long term equilibrium among variables is confirmed.first, the hypothesis of a cointegration test is written as follows:

$\mathrm{H} 0=\mathrm{W} 0=0 \quad \mathrm{i}=0,1, \ldots, \mathrm{k} \#$

To estimate ARDL model, first the number of optimium lags by SBC measures is estimated and then pattern coefficients are computed.

There are four microeconomic variables as independent variables and growth rate of cash stock return index as dependent variable. Table 1 shows each variable with its abbreviation.

Table 1. Each variable with its abbreviation

\begin{tabular}{cc}
\hline abbreviatin & variables \\
\hline CPI & Exchange rate in free market \\
RCASH & The growth rate of consumer price index for goods and services \\
OR & Rate of cash growth \\
RTEDIX & Oil return \\
\hline
\end{tabular}

Data of each variable was extracted quarterly from Central Bank of Iran's website, economic indices, and stock indices. This study examined the relationship of microeconomic variables like inflation rate, exchange rate, cash growth rate, oil return, growth rate of cash stock return index. Research hypotheses and their theories will be examined as follows:

\section{Inflation rate}

In inflation condtions, nominal return of the companies decreases after a while and increases for the decrease of money value. Thus, increasing inflation rate enhences dividend and cash stock return index. Accordingly, first hypothesis was formed as follows:

\section{H1. There is a positive correlation between inflation rate and cash stock return index.}

\section{Exchange rate}

The role of exchange in economic systems especially in developed countries is undeniable. Its reason is that underdeveloped countries are dependent on developed countries in many economic sections and they need more exchange for import. Most manufacturing corporations import goods in the form of raw materials, technology, and machinery. If exchange rate increases as a result of economic changes and other factors like exchange rate, economic corporations have to pay more for imports. Increasing exchange rate increases debt rate from one side and finished products and services from the other side. Increasing debt leads to cash shortage and this leads to negative effects on return distribution and cash stock return index. Thus, second hypothesis was formed as follows:

\section{H2. There is a negative correlation between exchange rate and growth rate of cash stock return index.}

\section{Cash growth rate}

Based on monetary theory of inflation, continuous increase of cash amount with a rate over multiplying the growth rate of real income by income elasticity of demands for money is a necessary condition for the continuous inflation. Thus, the increase of cash volume enhances demands and current costs. Researches on monetary theory of inflation showed that cash increase is not along with the increase of GDP and intensifies inflation. Thus, it is expected that the correlation of cash growth rate and cash stock return index is positive. Accordingly, the third hypothesis is stated as follows:

H3.There is a positive correlation between cash growth rate and growth rate of cash stock return index.

Oil return 
Although increasing oil price enhances GDP for oil exporting countries, the point to remember is that final consumer of oil derivatives is developing countries. Since oil-exporting countries are the main importing oil derivatives for not having necessary technologies for processing petroleum, the increase of oil price enhances the finished cost of produced products in industrial countries, increasing the cost of imports to developing countries like Iran. Since the expectation is a negative correlation between the increase of oil return and cash stock return index, H4 was formed as follows:

H4. There is a negative correlation between oil return and cash stock return index.

\section{Results}

Augmented Dickey Fuller unit root test

Since time series are inconsistent in microeconomic studies, it provides the possibility of occurring psudo-regression in experimental studies; thus, the consistency of the variables was tested by augmented Dickey Fuller unit root test whose results are shown in Table 1.

To select optimum lags, Schwarts-Bayesian criterion was used.

Table 1. Summary of the results for Extended Dickey Fuller unit root test

\begin{tabular}{ccccc}
\hline row & Cointegration degree & Critical value of & \multicolumn{3}{c}{ Time series } \\
& & ADF & ADF value & \\
\hline 1 & $(1) \mathrm{I}$ & -2.9287 & -6.6834 & EX \\
2 & $(1) \mathrm{I}$ & -2.9287 & $11.1736-$ & CPI \\
3 & $(0) \mathrm{I}$ & -2.9287 & $3.7716-$ & RCASH \\
4 & $(1) \mathrm{I}$ & -2.9287 & $8.4214-$ & OR \\
5 & $(1) \mathrm{I}$ & -2.9287 & $26.9879-$ & RTEDIX \\
\hline
\end{tabular}

Hypothesis test by self-regressing via distributional $\mathrm{s}$

Since this study probes the long-term correlation of microeconomic variables and cash stock return index. Regarding the difference of collective degree of the variables and using Microfit 4 software and Schwarts-Bayesian criterion, the best model with a proper lag was estimated by ARDL method. Schwarts- Bayesian criterion economizes in the number of $s$. As a result, such an estimation will have higher degree of freedom (Pesaran, 1997). Results of model estimation are shown in Table 2.

Table 2. Coefficients of corrected pattern

\begin{tabular}{lllll}
\hline prob & T value & sd & coefficient & Explanatory variable \\
\hline 0 & 6.4 & 0.07 & 0.69 & RTEDIX(-1) \\
0 & 0.08 & 8.7 & 0.74 & CPI \\
0 & -1.5 & 9.2 & -13.9 & CPI(-1) \\
0 & 4 & 8.6 & 34.4 & CPI(-2) \\
0 & -0.6 & 7.6 & -5 & RCASH \\
0 & -0.5 & 4.9 & -2.7 & RCASH(-1) \\
0 & 2.4 & 6.8 & 16.2 & RCASH(-2) \\
0 & -2.8 & 7.39 & -20.7 & RCASH(-3) \\
0 & -1.06 & 0.01 & -0.01 & EX \\
0 & 1.5 & 0.01 & 0.02 & EX(-1) \\
0 & -2.9 & 0.01 & -0.03 & EX(-2) \\
0 & 1.06 & 0.001 & 0.001 & OR \\
0 & -1.63 & 0.001 & -0.002 & OR(-1) \\
0 & -2.2 & 0.001 & -0.003 & OR(-2) \\
0 & -3.8 & 0.001 & -0.004 & OR(-3) \\
0 & 3.7 & 13.7 & 51.6 & T
\end{tabular}

\begin{tabular}{llll}
\hline A: Serial Correlation & CHSQ(4) $=6.4089[0.17] ;$ & B: Functional Form & CHSQ(2)=1.6553[0.20] \\
C: Normality & CHSQ $(1)=12.9502[0.002] ;$ & D: Heteroscedasticity & CHSQ(1) $=2.5097[0.11]$
\end{tabular}

The values below Table 2 shows the lack of self-correlation between variables, error and the variance of heteroscedasticity in the model. $f$ value at significance level of $5 \%$ shows that the whole regression equation can not be rejected statistically. Thus, explanatory power of the model is 0.99 . Before estimating long-term coefficients by ARDL method and to make sure about the existence of long-term correlation between economic variables and growth rate of 
cash return index, co-integration test is needed. For such a test, coefficients' sum with the lag of dependent variable (RTEDIX) is subtracted from 1 and divided into its standard deviation:

$$
t=\frac{\sum_{i=1}^{p} \hat{\Phi}_{i}-1}{\sum_{i=1}^{p} S_{\hat{\Phi}_{i}}}=\frac{0.69-1}{0.07}=-4.42
$$

H0 implying the lack of long-term correlation was rejected at 95\% confidence level. Thus, there is a long-term correlation between economic variables and the growth rate of cash return index. Long-term model was estimated by ARDL method whose results are shown in Table 3.

Table 3. Long-term pattern of ARDL method

\begin{tabular}{cccccc}
\hline prob & T value & sd & coefficient & $\begin{array}{c}\text { Explanatory } \\
\text { variable }\end{array}$ & $\begin{array}{c}\text { Explanatory } \\
\text { variable }\end{array}$ \\
\hline 0.04 & $2.1-$ & 0.04 & -0.08 & EX & EX \\
0.32 & $1.01-$ & 39.4 & -39.9 & RCASH & RCASH \\
0.06 & $1.9-$ & 0.01 & -0.03 & OR & OR \\
0.05 & 2.07 & 33.2 & 69 & CPI & CPI \\
0.00 & 7065 & 22 & 168 & T \\
\hline
\end{tabular}

Regarding $t$ value in Table 3, the coefficient of exchange rate, oil return, inflation rate, and time trend is significant at $90 \%$ significance level. But, the significance of cash growth rate coefficient is rejected at $90 \%$ confidence level. In that long-term correlation, exchange rate and oil return are negatively correlated. While, inflation rate and growth rate of cash stock return index are positively correlated. Then, if exchange rate and oil return increase 100 units $(3$ and $8 \%$ respectively), growth rate of cash stock return index decreases. Also, time pass and the increase of inflation rate have positive effects on increasing the growth rate of cash stock return index. The reason for that is that the policies of dividing earnings in stock companies increases by the time pass.

After estimating long-term model, the pattern of correcting the error related to it was offered; results of error correction are shown in Table 4.

Table 4. Short-term dynamic structure

\begin{tabular}{lllll}
\hline $\mathrm{p}$ & & $\mathrm{s}$ & & $\mathrm{v}$ \\
\hline 0 & 0 & 7 & 5 & $\mathrm{~d}$ \\
0 & 0 & 8 & 4 & $\mathrm{~d}$ \\
0 & 2 & 7 & 2 & $\mathrm{~d}$ \\
0 & 1 & 0 & 0 & $\mathrm{~d}$ \\
0 & 2 & 0 & 0 & $\mathrm{~d}$ \\
0 & 1 & 0 & 0 & $\mathrm{~d}$ \\
0 & 3 & 0 & 0 & $\mathrm{~d}$ \\
0 & 3 & 0 & 0 & $\mathrm{~d}$ \\
0 & 0 & 8 & 0 & $\mathrm{~d}$ \\
0 & 4 & 8 & 3 & $\mathrm{~d}$ \\
0 & 3 & 1 & 5 & $\mathrm{~d}$ \\
0 & 2 & 0 & 0 & $\mathrm{e}$ \\
\hline
\end{tabular}

What is considerable in short-term equation of ECM is $\operatorname{ECM}(-1)$ coefficient, showing the speed of short-trem imbalance towards long-term equilibrium.

As seen in Table 4, estimated coefficient of $\operatorname{ECM}(-1)$ is about -0.3 showing relatively high speed of removing short-trem imbalance towards long-term equilibrium. It shows that in each period, 0.3 of imbalance in stock cash return index is removed.

\section{Conclusion}

Since people keep a different combination of cash, stocks, deposits, securities, gold, and exchange in their financial portfolios, changes in money volume, exchange rate, inflation rate, and interest rate affect people's demands for keeping any of these assets like demands for the stocks. This affects stock indices. The belief is that stock prices are identified by some economic variables like inflation rate, exchange rate, interest rate, and cash flow.

To estimate econometric model and long-term correlation, ARDL method was used. Results of co-integration test showed a long-term correlation between inflation rate, exchange rate, cash growth rate, and oil return with growth rate 
of stock cash return index. Thus, by ARDL method, long term correlation was estimated. Like expectations, in long term and inflation conditions, nominal return of the companies increases for reducing money value. Thus, increasing inflation rate leads to divisions and stock cash return index. Results of $\mathrm{H} 1$ confirmed a positive correlation between inflation rate and growth rate of stock cash return index. While, cash growth rate coefficient is not significant at $95 \%$ confidence level in ARDL long term pattern. No long-term correlation was observed. Thus, H3 was rejected.

Results of H1 and H3 agree with Muradoglu and Metin (1996) and Lili and Zvliv (1998) but disagree with Madsen (2002).

$\mathrm{H} 2$ and $\mathrm{H} 4$ implying the negative correlation between exchange rate and oil return with growth rate of stock cash return index were accepted at $95 \%$ confidence level. The lack of significant correlation between the coefficient of real bank return rate and exchange rate in ARDL showed that there is no correlation between these two variables and total growth rate index of stock price. Thus, $\mathrm{H} 2$ and $\mathrm{H} 4$ were rejected. This disagrees with Muradoglu and Metin (1996).

Although the correlation of inflation rate and cash return index is positive, such an increase is for compensating for real benefit. Thus, economic policy makers and decision-makers should consider the effects of such decisions on the indices of stock market and other financial markets during providing monetary and financial policies at micro level.

\section{Suggestions}

Based on the results of this study and previous studies economic variables affect general index of stock price. Since the correlation of these variables is negative, decision makers and economic policy makers should consider the effects of those decisions on the indices of stock market and other financial markets during providing monetary and financial policies. Also, economic policy making organizations should provide a consistent decision-making system in capital market to increase private investment economic growth. Also, correct management and on time exchange and inflation shocks can provide the benefits of investors and support their interests.

\section{References}

Achsani, N., \& Strohe, H. G. (2002). Stock market returns and macroeconomic factors, Evidence from Jakarta Stock Exchange, Indonesia 1990-2001, Discussion Paper.

Boudoukh, J., \& Richardson, M. (1993). Stock returns and inflation: A long-horizon perspective, American, Economic Review, March, 1346-1355.

Caparale, T., \& Jung, C. (1997). Inflation and real stock prices, Applied Financial Economics, June, 265-266. http://dx.doi.org/10.1080/096031097333619

Chatrath, A., Ramchander, S., \& Song. F. (1997). Stock prices, infaltion and output: Evidence from India, Applied Financial Economics, August, 439-455. http://dx.doi.org/10.1080/096031097333556

Chen, N. F., \& Roll, S. A. (1986). Economic Forces and the Stock Market, Journal of Business, 59(3), 383-403. http://dx.doi.org/10.1086/296344

Cheung, Y. W., \& Ng. International Evidence on the Stock Market and Aggregate Economic Activity, Journal of Empirical Finance, 5, 281-296. http://dx.doi.org/10.1016/S0927-5398(97)00025-X

Christopher, G. et al. (2006). Macroeconomic variables and stock market interactions: New Zeland evidences, Journal of Investment Management and Financial Innovation, 89-101.

Elton, E. J., \& Gruber, M. (1991). Modern portfolio theory and investment analysis, Fourth Edition, John Wiley \& Sons.

Fama, E. F. \& Gibbons, M. (1982). Inflation, Real Returns and Capital Investment, Journal of Monetary Economics, 9(3), 545-565.

Fama, E. F. (1981). Stock returns, real activity, inflation and money, American Economic Review, 71(4), 545-565. http://dx.doi.org/10.1016/0304-3932(82)90021-6

Fama, E. F. (1990). Stock returns, expected returns and real activity, Journal of Finance, 45, 1089-1108. http://dx.doi.org/10.1111/j.1540-6261.1990.tb02428.x

Feldstein, M. (1980). Inflation and the Stock Market, American Economic Review, 839-847.

Fung, H. G., \& Lie, C. J. (1990). Stock market and economic activities: A casual analysis. Pacific- Basin Capital Markets Research, Amsterdam.

Geske, R., \& Roll, R. (1983). The Fiscal and Monetary Linkage between Stock Returns and Inflation, Journal of Finance, 38(1), 7-33. http://dx.doi.org/10.1111/j.1540-6261.1983.tb03623.x

Graham, F. C. (1996). Inflation, real stock returns, and monetary policy, Applied Financial Economics, Feb, 29-35. 
http://dx.doi.org/10.1080/096031096334448

Gultekin, N. B. (1983). Stock market returns and inflation: Evidence from other counties, The Journal of Finance, March, 49-65. http://dx.doi.org/10.1111/j.1540-6261.1983.tb03625.x

Hamao, Y. (1988). An empirical investigation of the arbitrage pricing theory, in Elton E. J. and M. J. Gruber (eds), Japanese Capital Markets, Analysis and Characteristics of Equity, Debt and Financial Futures Markets, Ballinger Publishing Company, United States, 155-173.

Harry, M. (1959). Martkowitz: Portfolio Selection: Efficient Diversification of Investments, New York: Wiley.

Hernandez, L. (1990). Inflation Y Retorno Bursatil, Una Invetigacion Empricia: Chile 1960-1983", Cuadernos-De-Econmia, December 1990, 381-406.

Kwon, C. S., \& Shin, T. S. (1999). Cointegration and Causality between Macroeconomic Variables and Stock Market Returns, Global Finance Journal, 10(1), 71-81. http://dx.doi.org/10.1016/S1044-0283(99)00006-X

Laidler, D. E. W., \& Parkin, J. M. (1975). A Survey, Economic Journal, 795.

Lee, B. S. (1992). Casual relations among stock returns, interest rates, real activity, and inflation, Journal of Finance, 47(4), 1591-1603. http://dx.doi.org/10.1111/j.1540-6261.1992.tb04673.x

Lee, U. (1996). Further empirical test of the proxy effect hypothesis: Some international evidence, Journal of International Financial Market Institution and Money, summer, 35-46.

Leigh, L. (1997). Stock return equilibrium and macroeconomic fundamentals, International Monetary Fund Working Paper, 97(15), 1-41.

Levine, R., \& Servos, S. (1996). Stock market development and long-run growth, The World Bank Economics. 10(2), 323-339. http://dx.doi.org/10.1093/wber/10.2.323

Li, L., \& Zvliv, H. (1998). Responses of the stock market to macroeconomic announcements across economic states, IMF Working Paper, 93-97.

Madsen, J. (2002). Share returns and the Fisher hypothesis reconsidered. Applied Financial Economics, 12, 565-574. http://dx.doi.org/10.1080/09603100010012980

Maysami, R. C., \& Koh, A. (2000). Vector error correction model of the Singapore Stock market, International Review of Economics and Finance, 9, 79-96. http://dx.doi.org/10.1016/S1059-0560(99)00042-8

Mukherjee, T. K., \& Naka, A. (1995). Dynamic relations between macroeconomic variables and the Japanese Stock Market: An application of a vector error correction model, Journal of Financial Research, 18(2), 223-237. http://dx.doi.org/10.1111/j.1475-6803.1995.tb00563.x

Mundell, R. A. (1963). Inflation and Real Interest, Journal of Political Economy, 71(3), June, 280-283. http://dx.doi.org/10.1086/258771

Muradoglu, Y., \& Metin, K. (1996). Efficiency of the Turkish Stock Exchange with respect to monetary variables: A cointegration analysis. European Journal of Operational Research, 90, 566-576. http://dx.doi.org/10.1016/0377-2217(95)00071-2

Najand, M., \& Rahman, H. (1991). Stock Market Volatility and Macroeconomic Variables: International Evidence, Journal of Multinational Financial Management, 1(3).

Pesaran, M. (1997). Working with Microfit 4.0 Comfit Data Limited, 304-308.

Pesaran, M. H., \& Shin, Y. (1999). An Autoregressive Distributed-Lag Modelling Approach to Cointegration Analysis; In Econometrics and Economic Theory in the 20th Century, The Ragnar Frisch Centennial Symposium (S. Strom, ed.), 371-413. Cambridge University Press. Cambridge. http://dx.doi.org/10.1017/CCOL521633230.011

Poon, S., \& Taylor, S. J. (1991). Macroeconomic Factors and the UK Stock Market, Journal of Business and Accounting, 18(5), 619-636. http://dx.doi.org/10.1111/j.1468-5957.1991.tb00229.x

Richard, R., \& Stephen, A. (1980). An Empirical Investigation of the Arbitrage Pricing Theory, Journal of Finance, 35, December.

Richard, R., \& Stephen, A. (1984). The Arbitrage pricing theory approach to strategic portfolio planning, Financial Analysts Journal, 40, May-June.

Ross, S. A. (1976). The arbitrage theory of capital asset pricing, Journal of Economic Theory, 13(3), 341-360. http://dx.doi.org/10.1016/0022-0531(76)90046-6 
Sadeghi, M. (1992). Stock market response to unexpectrd macroeconomic news: The Australian evidence.

Thorbecke, W. (1997). On stock market returns and monetary policy, The Journal of Finance. June, 635-653. http://dx.doi.org/10.1111/j.1540-6261.1997.tb04816.x

Tobin, J. (1965). Money and economic growth, Econometric, 33(4), 671-684. http://dx.doi.org/10.2307/1910352

\section{Copyrights}

Copyright for this article is retained by the author(s), with first publication rights granted to the journal.

This is an open-access article distributed under the terms and conditions of the Creative Commons Attribution license (http://creativecommons.org/licenses/by/3.0/). 